This item was submitted to Loughborough's Research Repository by the author.

Items in Figshare are protected by copyright, with all rights reserved, unless otherwise indicated.

\title{
Using BIM to integrate and achieve holistic future-proofing objectives in healthcare projects
}

\section{PLEASE CITE THE PUBLISHED VERSION}

http://dx.doi.org/10.1080/01446193.2016.1164326

\section{PUBLISHER}

(C) Taylor \& Francis (Routledge)

\section{VERSION}

AM (Accepted Manuscript)

\section{PUBLISHER STATEMENT}

This work is made available according to the conditions of the Creative Commons Attribution-NonCommercialNoDerivatives 4.0 International (CC BY-NC-ND 4.0) licence. Full details of this licence are available at: https://creativecommons.org/licenses/by-nc-nd/4.0/

\section{LICENCE}

CC BY-NC-ND 4.0

\section{REPOSITORY RECORD}

Krystallis, llias, Peter Demian, and Andrew Price. 2016. "Using BIM to Integrate and Achieve Holistic Futureproofing Objectives in Healthcare Projects”. Loughborough University. https://hdl.handle.net/2134/20694. 
Krystallis et al. 2016. "Using BIM to integrate and achieve holistic future-proofing objectives in healthcare projects”, Construction Management and Economics

\section{Introduction}

Healthcare and its executive teams face a policy environment characterised by change on several fronts (e.g. reforms in health services, government initiatives for improving working conditions of staff etc.). With change there is uncertainty and thus has an impact on the ongoing delivery of service strategies, organisational culture and the way the Trusts (divisions within the UK’s National Health Service, NHS) operate locally. According to Capper et al. (2012) the main issue is the reluctance of the NHS system to enforce strategies that will address sustainability related planning conditions.

Healthcare assets exist in a complex operational and technological environment and thus identifying the Requirements Information (from early concept stages) from a whole-life information management perspective is crucial for ensuring design life. Additionally, global austerity measures are causing reduction of investments in all sectors, and the construction sector is no exception. However, owners are seeking other ways to overcome the financial crisis by investing in the application of sustainability; and for a building to achieve sustainability the designers recognise that it has to be also future-proofed (Krygiel \& Nies, 2008). While the traditional idea was to design and deliver healthcare facilities as "complete" projects, in other words projects with fixed requirements; it has transpired that hospitals are very complex dynamic facilities and cannot be built as programmatically static (Carthey et al. 2010; de Neufville et al. 2008; Kendall 2005; Thomson et al. 1998). In this context, Francis (2010) stressed the question "how can we ensure that what we are building now will be fit for the future?” and then proposed that a dynamic system approach is necessary to deal with change.

Masood et al. (2013) suggested that "information could also play an important role in supporting whole-life decision-making”. In support of the above and following the USA and 
Krystallis et al. 2016. "Using BIM to integrate and achieve holistic future-proofing objectives in healthcare projects”, Construction Management and Economics

the Scandinavian countries as previous successful examples, the UK has set forth a BIM initiative which emerged from the 2011 construction strategy (Cabinet Office, 2011) and suggests that construction savings can be achieved if the construction industry manages better the information it produces. One of the key challenges from a planning point of view is whether information will be fit for purpose in the long-term. At the outset, a definition of the two concepts, BIM and future-proofing, needs to be drawn. The UK Department of Health (DH, 2013) recognised 13 issues that need to be addressed at each project stage of a healthcare project regarding excellence in sustainability; one of them being future-proofing. Masood et al (2013) defined future-proofing as "the process of incorporating future developments while changing from an unplanned and uncontrolled state to a planned and controlled state of a resilient infrastructure asset or product service system with minimal negative consequences”. For the DH (2013) future-proofing is a response where "buildings should respond to future changes in requirements, change of use, strategic perspectives, clinical/medical drivers, national policy and changing climate”. In the remainder of this paper, future-proofing is proposed as the dynamic system approach that can address change.

There have been many definitions of BIM and all of them describe a change in process in terms of construction management (Demian \& Walters 2014; BSI 2014; BSI 2013; Ashworth 2012; Eastman, et al. 2011; Shade, et al. 2011; BSI 2007). For the purposes of this research, BIM can be defined as:

Building Information Modelling (as a verb) is the process of generating and managing component data within an integrated database and parametric model throughout the project's Design-Build-Operate lifecycle.

The result is a Building Information Model and can be defined as: 
Krystallis et al. 2016. "Using BIM to integrate and achieve holistic future-proofing objectives in healthcare projects”, Construction Management and Economics

A Building Information Model (as a noun) is a digital representation of all physical and functional characteristics of a facility or site serving as a shared knowledge resource for information about the assets. This knowledge database forms a reliable basis for information exchange and decisions during a project's lifecycle from inception onward.

The parallel adoption of these two concepts could bring confusion when clients and the supply chain assess their impacts and effectiveness. Does BIM have the capabilities to support a planning approach that prepares the asset against future changes in requirements? Which characteristics of BIM assist more and which could potentially hinder future-proofing flows? What are the synergies of future-proofing and BIM? What are the benefits of working towards these two concepts?

The aim of this study is to develop a classification ontology of the interactions between the two concepts, based on empirical evidence that emerged from interviews with 13 senior managers experienced in healthcare design, construction and operation and BIM. These interactions establish the theoretical relationships that exist between the two concepts through a framework that juxtaposes future-proofing objectives throughout the project lifecycle, and BIM capabilities related to a future-proof whole-life management. These interactions should also clarify how BIM can be implemented for maximum alignment to future-proofing.

To accomplish the aim we:

- Articulated future-proofing objectives using a holistic approach. An objective is defined as a set of tasks taking place to accommodate one high level goal at a particular project phase;

- Identified tasks that help implement future-proofing as part of project management. A task is defined as a particular action that is grouped with other tasks to complete a goal, thus an objective; 
Krystallis et al. 2016. "Using BIM to integrate and achieve holistic future-proofing objectives in healthcare projects”, Construction Management and Economics

- Identified which BIM capabilities contribute to the implementation of future-proofing strategies. A BIM capability is a particular feature of BIM that is used by the supply chain to develop, deliver, test and make use of particular information relevant to future-proofing; and

- Investigated whether BIM does indeed benefit any aspects of future-proofing.

\section{Literature Review}

\section{Holistic Future-proofing}

In literature, the concept of future-proofing covers areas such as protecting the built environment against climate change (Jentsch, et al., 2008), future-proofing buildings against future higher temperatures (Coley, et al., 2012), and energy efficiency (Georgiadou, et al., 2012). In addition, national and local frameworks have emerged, with a focus on effectively managing public health risks to achieve climate resilience (HM Government, 2013).

As discussed above, future-proofing has often been presented as a process that deals with environmental and energy saving issues but healthcare organisations are dealing with change in many more additional aspects. Criticality plays a major role in healthcare; unlike other types of buildings, healthcare buildings cannot afford major redesigning because of the impact this will have in the clinical service provision. From a client point of view, there have a number of procurement methods that would specify healthcare project delivery and thus how futureproofing could be approached; all of them having advantages and disadvantages. Public-private partnerships (PPP) and Private Finance Initiatives (PFI) are commonly practiced in the UK for their long concession periods (Javed, et al., 2014). Fast-track procurement is often a preferred option because of the overlapping ability to undertake delivery tasks. However this comes with increased risks and costs (Bogus, et al., 2006). Integrated Project Delivery (IPD) is branded as a non-traditional method where the teams come together early utilising innovative technologies 
Krystallis et al. 2016. "Using BIM to integrate and achieve holistic future-proofing objectives in healthcare projects”, Construction Management and Economics

and thus collaboration is increased (Lahdenperä, 2012). As an alternative route, the client may choose the Design-Build type of contract but evidence has shown that these types of methods may bring confusion regarding the designer/contractor role (Larsen \& Whyte, 2013). In order to increase building and operational performance, there is an increased number of clients which impose a Soft Landings framework in their tender documents where the supply chain is obliged to be involved after the handover of the project (Way \& Bordass, 2007).

We have summarised a list of tasks found in literature (Table 1) and covers future-proofing with regards to the whole project phases. The objectives emerged from the literature analysis and in essence they serve to categorise/group tasks with similar scope and aim; they are described in detail later in this paper. Having a set of tasks from the literature, interviews where then used to identify additional tasks that will give us a more complete aspect of implementing future-proofing in healthcare projects.

\section{'Insert Table 1a here’ \\ 'Insert Table $1 b$ here' \\ 'Insert Table 1c here’}

\section{BIM for Future-proofing the Healthcare Built Environment}

Research on ecological landscapes suggested that institutional and organisational landscapes could be approached the same way, in order to contribute to the resilience of socio-ecological systems (Olsson, 2004). The features identified by the authors included: legislation that creates social space; funds availability for responding to environmental changes and for remedial actions; ability to respond and monitor environmental feedback; information flows and social networking; combination of various sources of information; sense-making of the collected information; and platforms of knowledge sharing. 
Krystallis et al. 2016. "Using BIM to integrate and achieve holistic future-proofing objectives in healthcare projects”, Construction Management and Economics

Most of the above features can be applied in today’s construction 'ecosystem' too and moreover, information workflows, collaborations and interacting communication platforms are achieved by embracing BIM principles. The Cabinet Office BIM Task Group stated that BIM is "a managed digital information 3D model of an asset, be it a building or an infrastructure project (both new-build or retained estate) that is infused with data. This information can be used to inform the decision-making process and answer questions throughout the entire project lifecycle. One BIM input can give us many valuable outputs” (NBS \& RIBA Enterprices, 2012). BIM has the capability to affect the core processes and products of design and construction and affect all the professions evolved in throughout the project lifecycle (CIC 2013; Eastman, et al. 2011; AIA 2007). BIM also warrants an innovative approach at information flows and communication in design and later in construction (Demian \& Walters, 2014). The MacLeamy curve highlights that the required time of design and construction delivery can be shortened significantly by to the adoption of BIM processes as opposed to traditional delivery methods. Also, adoption of BIM workflows and the impact of cost and performance are highly associated as both factors influence (can be influenced by) the early stages of the projects and are interconnected (Light, 2011). In early design phases, BIM can be used to facilitate various model based scenarios and influence decision-making (Shade, et al., 2011). One of the great impacts in construction is that everyone in the industry can not only share data but in addition this data is shared through a common platform (Ashworth, 2012). For design, BIM signals a paradigm shift from drafting to modelling, which enables design decisions to be made with more foresight. BIM can be used as a central repository for building project information throughout the asset’s lifecycle (Grilo \& Jardim-Goncalves, 2010). However, in the designers' views, 3D models that are used in design do not have the maturity yet or the FM teams have not developed process that can use these models in relation to the benefits provided by the maintenance systems they already use (Korpela, et al., 2015). 
Krystallis et al. 2016. "Using BIM to integrate and achieve holistic future-proofing objectives in healthcare projects”, Construction Management and Economics

In healthcare construction, an example where facility and clinical information are linked to support managing healthcare facilities was presented in Lucas et al. (2013). Innovative engagement processes as part of a BIM based solution were used to enhance decision-making in healthcare facility management (Irizarry et al., 2014), while a healthcare related problem scenario where BIM and healthcare specialist software ActivityDatabase are used concurrently on refurbishment projects was presented by Krystallis et al. (2013). It seems that healthcare is a sector where BIM can be exploited in many more innovative ways.

In summary, the two concepts are two independent initiatives in the UK (BIM is pushed by the BIM task group (http://www.bimtaskgroup.org/) whilst future-proofing is part of the sustainability agenda proposed by the Department of Health (DH, 2013). There seems to be a lack of systematic investigation of the interplay between the two concepts. It seems that additional evidence is required to explore whether the two concepts are dependent on one another and if they are, then to what extent. In the remainder of the paper an attempt is made to identify the interrelationships that exist between the two.

\section{Research Method}

\section{Interpretative Phenomenological Analysis}

The study adopted Interpretative Phenomenological Analysis (IPA) for recordings of perceptions. The aim of IPA “is to explore in detail how participants make sense of their personal and social world, and the main currency for an IPA study is the meanings particular experiences, events, states hold for participants” (Smith, 2010). Both IPA and Thematic Analysis (TA) could have been used for data analysis, but IPA was chosen due to the fact that future-proofing was studied as a phenomenon and the nature of the interview questions were closely related to that type of method. The theoretical lens used in analysing and interpreting 
Krystallis et al. 2016. "Using BIM to integrate and achieve holistic future-proofing objectives in healthcare projects”, Construction Management and Economics

the perspectives of the interviewees comes from the cognitive rather than the behaviourist paradigm that is broadly used in social sciences (Smith, 1996).

The 'first-order' stage analysis took place once all the transcripts were completed (Larkin, et al., 2006). A transcript was randomly picked and was read several times. First, initial themes were documented followed by emergent themes. The emergent themes were grouped together to provide 'grouped' themes, which in turn were reconstructed into High-level, Mid-level and Low-level themes according to the focus level they addressed (Larkin, et al., 2006). The same process was followed with the rest of the transcripts, and the grouped themes that emerged were aligned back to the first set of high-, mid- and low-level themes that arose from the previous transcripts and wherever that was not possible new themes were added.

The 'first order' stage summarises the participants' concerns and does not develop any further interpretative or conceptual level (Larkin, et al., 2006). That 'interpretation' was done in the 'second-order' stage, where the investigator provided a critical and conceptual commentary upon the sense-making perceptions of the participants (Smith \& Osborn, 2008). In this second stage, engagement with existing theoretical constructs as well as interpretations about 'what it means' were used for the development of the framework (Table 6). More information about the conceptualisation of the framework can be found in Sacks, et al. (2010). At this stage, we quantified the items found under future-proofing implementation and mapped them against the identified BIM capabilities, both of which emerged from the IPA interpretative part.

\section{IPA Analytic Process}

Firstly, we conducted a literature search about future-proofing and selected sources which discuss it from a broad research spectrum. These were put together in task form and placed in a catalogue (pool of tasks). Then, we undertook interviews with healthcare experts and two themes emerged from the data, the first being future-proofing specific and the second for BIM 
Krystallis et al. 2016. "Using BIM to integrate and achieve holistic future-proofing objectives in healthcare projects”, Construction Management and Economics

capabilities related to future-proofing. The first theme offered a new set of tasks which in turn were added to the catalogue, together with the tasks derived from the literature. A summary table of the background of the interviewee healthcare experts is presented in Table 2. Table 1 outlines the tasks found in literature; the tasks identified by the interviewees are summarised in Table 3. The objectives shown in Table 1 come from Table 5 and were used to group tasks with similar scope.

Each task was assigned a label according to the project phase in which it is found (i.e. P-I is a task found in [P]lanning phase etc., and the Roman numerals indicate the sequence of the objective within a particular phase). The BIM capabilities that were found are presented in Table 4. A combination of both sources of tasks (literature and interview data) was used and the outcome was the development of the objectives (Table 5) where they were further aligned to project phases. We developed an interaction matrix (Table 6) after analysing the interrelationships in the cross tabulations of the objectives (Table 5) and the BIM capabilities (Table 4). The table summarises the interactions by counting each interaction as it occurs throughout the identified phases. All interactions emerged from the IPA analysis and later the results were quantified to 'weight' the interactions against the framework and thus giving a whole-life perspective of the two concepts.

This interaction matrix aims to underpin theoretical relationships that exist between the two concepts. An attempt was made to support the emerging interactions with empirical evidence coming from experts, as presented in Table 7 - Table 12. The inclusion of verbatim extracts in these tables "helps the reader to trace the analytic process, perhaps including more acknowledgment of analysts’ preconceptions and beliefs and reflexivity might increase transparency and enhance the account’s rhetorical power” (Brocki \& Wearden, 2006). 
Krystallis et al. 2016. "Using BIM to integrate and achieve holistic future-proofing objectives in healthcare projects”, Construction Management and Economics

\section{Sample}

Semi-structured interviews were conducted and the interviewees are both procurers (five Program and Owner Operators) and delivery side (eight consultants and major contractors). Furthermore these interviewees were selected for their specialist background in healthcare construction and understanding of BIM. Most of the interviewees had served in this area for more than 10 years and as such they had vast experience in different types of healthcare projects and procurement methods. Due to this, they were able to bring examples of good practice from various types of contracts, which would provide some reassurance of the generality of the results, irrespective of the type of contract used. In addition, the good balance between procurers and the delivery side reduced bias in the emergent themes towards the demand or supply side.

\section{'Insert Table 2 here'}

\section{Results and Discussion}

\section{Future-proofing aspirations}

The views of the interviewees with regards to aspects of future-proofing have been summarised into eight categories (Table 3). Each category reflects one particular capacity of the concept. Below the eight aspirations are discussed in detail and in addition the tasks found from the interview sessions have been mapped against the eight aspirations in Table 3:

1. Setting of initial future-proofing targets: The interviewees suggested that the setting of initial targets should be around establishing the principles for future-proofing in their design strategy. Those principles consider various aspects e.g. investigation of future services, clients’ information requirements regarding considerations, standardisation agenda etc.

2. Investment options: Future-proofing considerations can be used for Portfolio and Asset management. The interviewees highlighted awareness around business opportunities that 
Krystallis et al. 2016. "Using BIM to integrate and achieve holistic future-proofing objectives in healthcare projects”, Construction Management and Economics

may rise in the future of an operating healthcare asset and how these may reflect in the asset. The opportunities consider future collaborations with nearby private providers and distribution of services accordingly, provision of unused spaces for patient welfare etc.

3. Adaptive to future-proofing needs procurement method: Contractual agreements seem to hinder aspects of the concept and the interviewees highlighted particular parts of current methods they believed will enhance it. Among others, Fast-track was mentioned as a method suitable for addressing uncertainty (although it was recognised that adoption may increase costs by 20\%), which is also highlighted in (Bogus, et al., 2006); the Private Finance Initiative (PFI) as an example of extending the brief and Integrating Project Delivery (IPD) for involving the FM as early as possible.

4. Necessary building flexibility: An integral part future-proofing is having flexibility incorporated in the design. Speaking from experience the interviewees filtered the most useful concepts of flexibility that are usually used when delivering healthcare facilities. Sacrificial systems (i.e. walls with no M\&E systems input) and soft spaces (i.e. offices), concrete frames and open spaces have been mentioned among others.

5. Healthcare-specific design scenario factors: The interviewees identified the tasks they perform when looking at 'what-if' scenarios during the design process. Aspects such as activity projections, patients flow, room adjacencies etc. are some of what was identified by the interviewees to develop their business case.

6. Repeatable standardised spaces: Although at first sight standardisation may seem to contradict flexibility, there are particular features that make standardisation attractive for delivering future-proof solutions. For example, employing limited general NHS rooms was found to allow an existing space to be used for other uses. Repeatable spaces which 
Krystallis et al. 2016. "Using BIM to integrate and achieve holistic future-proofing objectives in healthcare projects”, Construction Management and Economics

improve service delivery (i.e. increase familiarity to staff coming from other hospitals) were mentioned too.

7. 'What-if' data for maintenance solutions: The data provided early in the project will be used to better support the FM decisions at the operational stage. Data such as maintenance equipment factors, projections of future use and how these will affect service maintenance could be incorporated into information exchange packages which may be used at later stages.

8. Adaptive management: Lastly the interviewees identified the importance of adaptive management for future-proof solutions. For example they suggested that lessons learnt from other sectors (e.g. oil and gas, and the automotive industry) where the production environment is always adaptable to new products (i.e. development of new cars while the workflow of existing cars continues) should be used as example to improve processes in the healthcare sector.

\section{'Insert Table 3 here’}

\section{BIM capabilities related to future-proofing}

This section summarises capabilities that relate to future-proofing as identified by the healthcare experts (Table 4). The capabilities are grouped into six categories and reflect the specific areas where BIM is used for implementing future-proofing. Additional BIM capabilities exist and have been documented in the literature (e.g. Eastman, et al. 2011; Sacks, et al. 2010), but not all of these necessarily add value to future-proofing in the experts' opinion. Identifiers have been added in Table 4 which refer to subsequent tables for further description of how the six categories found here are used for future-proofing and BIM.

\section{'Insert Table 4 here'}


Krystallis et al. 2016. "Using BIM to integrate and achieve holistic future-proofing objectives in healthcare projects”, Construction Management and Economics

\section{Holistic future-proofing objectives}

After interviewing the healthcare construction experts, the tasks presented in Table 3 emerged and were later compared against the tasks found in the literature (Table 1). These two sources of tasks were combined to draw out the following objectives (Table 5). At the top of the hierarchy, the objectives represent the overall scope of each category and are decomposed into tasks for each specific setting. These tasks focus solely on implementing future-proofing strategies and are intended to be used alongside standard procedures (e.g. CIC Scope of Services) when delivering a project. Compared to the aspirations presented in the previous section (Table 3), the objectives provide guidance on what deliverable is required at a particular phase. Future-proofing delivery is gradually developed at all phases which means that objectives found in each phase replace those from the phase before.

\section{'Insert Table 5 here’}

\section{Generation and Interpretation of the BIM-future-proofing Interaction matrix}

The framework is reviewed to test the support of the identified BIM capabilities (Table 4) to the holistic objectives (Table 5), as shown in Table 6. The matrix can be interpreted in many ways and valuable conclusions can be extracted regarding the synergy between the two concepts. Some of the interactions reflect project management interests, some design and construction issues and some reflect operation interests. The index numbers in the cells of Table 6 express an understanding of the BIM uses to implement future-proofing; the numbers are explained in the key tables, Table 7 - Table 12.

The cells are shadowed and reflect the level of association between a BIM capability and an objective and thus when a cell appears in a darker colour it means that the objective highly benefits from that BIM capability (many interactions support the objective); for light shaded 
Krystallis et al. 2016. "Using BIM to integrate and achieve holistic future-proofing objectives in healthcare projects”, Construction Management and Economics

cells there is less to no association (see label in Table 6). In addition, Table 7 - Table 12 use evidence from practice to support the identified interactions that emerged.

The objectives with the most interactions were found to be P-IV: Identification of flexibility (18) while P-I: future-proofing brief setting and D-III: Demonstration of flexibility plans shared 17 interactions each. In addition the implementation of D-III objective was found to be highly related to multiple BIM capabilities (4), while P-I and P-IV were found to be highly associated to (3) BIM capabilities each.

The BIM capabilities with the most interactions across a project's life-cycle were found to be Whole-life communication (64), Flexible data (40) and Standardised space catalogues (39). More specifically, Whole-life communication and Flexible data were found to have interactions in all objectives but one. The interactions that appear the most are Adaptable data for various actors (15), Benchmarks and recommendations (14) and Reducing the cost of resources with 13 interactions.

The objectives with the least number of interactions were P-III: Adaptive-friendly procurement method (0), followed by CO-II: future-proofing of working conditions (3), and Responsiveness of government strategic goals (6); the healthcare experts could not associate those objectives with any of the identified BIM capabilities. There could be several reasons for this: the experts do not find it useful to use BIM for such objectives, or they are not aware of how to use for these objectives. The weakest BIM capability was found to be Whole-life costing (26) when compared to the other capability categories.

Bynum et al. (2012) found that BIM has a stronger application in project coordination and visualisation than it has for sustainability. Others found that the representations offered by BIM do not necessarily make the exploration of design solution space more effective or efficient, and that AEC professionals find solutions through what some authors referred to as 'messy 
Krystallis et al. 2016. "Using BIM to integrate and achieve holistic future-proofing objectives in healthcare projects”, Construction Management and Economics

talk’ (Dossick and Neff, 2011). BIM was found not to foster collaboration across different companies, in contrast to increasing the collaboration among project members (Dossick and Neff, 2010). Non-technical organisational maturity was found to be more important than technological maturity in companies interested in adopting BIM. Researchers suggested that non-technical readiness should be addressed before technological readiness (Won, et al., 2013).

Interoperability issues are recognised and have been documented in a number of studies. Manning and Messner (2008) looked at healthcare case studies and found data transfer bottlenecks and a later study found that the industry had not yet found a way to resolve interoperability issues (Bynum, et al., 2012). Return on investment (ROI) issues have been discussed widely in literature, and Giel (2009) found that ROI is greater as the complexity of the project increases, thus making it more difficult to justify the need for BIM for smaller scale projects.

\author{
'Insert table 6 here’ \\ 'Insert Table 7 here' \\ 'Insert Table 8 here' \\ 'Insert Table 9 here' \\ 'Insert Table 10 here' \\ 'Insert Table 11 here' \\ 'Insert Table 12 here'
}

\title{
Conclusions
}

In literature the two concepts are presented as two different initiatives and are not interconnected although they both seem to be focusing on change. Based on this, a classification ontology was created for assessing the interactions of the two concepts in 
Krystallis et al. 2016. "Using BIM to integrate and achieve holistic future-proofing objectives in healthcare projects”, Construction Management and Economics

question as they emerge in the healthcare built environment. The findings are two-fold: a holistic approach to the concept of future-proofing is provided. A list of objectives and tasks provide a thorough approach to future-proofing as a delivery concept as opposed to being solely a design (DH, 2013; NHS Confederation, 2005), sustainability (Krygiel \& Nies, 2008; Georgiadou, et al., 2012) or investment solution (World Bank, 2010). In addition, a metacritique analysis of BIM was presented and the strengths and weakness of this process as it is reflected in the implementation of future-proofing is presented.

The 30 interactions were found to be repeated 237 times across Table 6. In terms of how a future-proofing strategy is progressing across the project stages the findings suggest it is at the early design stages where the preparation against uncertainty occurs regarding the asset life.

\section{'Insert Figure 1 here’}

For benefits realisation in the context of the two concepts, after distilling the 30 interactions it can be concluded that whole-life communication is the most relevant capability of BIM for implementing future-proofing and thus the objectives can be clearly communicated within the project's lifespan. The interviewees could better associate the objectives to organisational and building performance through BIM. In addition, BIM supports the development of lifecycle operation information via becoming a communication platform and thus ensuring 'data maintainability’.

Future-proofing and 'traditional' project data are being produced at a similar pace and during the operation stage additional operation data are being captured which results in information that supports and updates / maintains the adopted future-proofing strategy. In contrast, BIM for whole-life costing has not yet matured and more investigation is required. The above are summarised in Figure 1. 
Krystallis et al. 2016. "Using BIM to integrate and achieve holistic future-proofing objectives in healthcare projects”, Construction Management and Economics

The 30 interactions documented in Table 6 and Table 7 - Table 12, present evidence from practice and demonstrate the strong synergy between the two concepts in healthcare construction projects. One limitation is that for projects with less complexity, BIM might in fact cause more challenges than benefits.

BIM processes drive rather than enhance future-proofing implementation and that derives from an 'all-inclusive' observation of the emerged interactions. BIM is used as the vehicle for delivering objectives at all phases and many of the interactions are repeated - carried over from one phase to the next. BIM itself is not a concept with clear start and end times in project management; it is a multifaceted ongoing process where its capabilities are used to support and improve many concepts found in the built environment.

In addition, the taxonomy is supported with empirical evidence which showcases in detail the practical issues faced in projects implemented in BIM and future-proofing. Much like the equivalent interconnections between BIM and lean (Sacks, et al., 2010) the findings imply that delivery teams and clients working on encompassing future-proofing in their delivery strategy should ensure that their processes are adapted to meet the BIM principles.

On the other hand, the high number of interactions may suggest that a step change is required to include future-proofing in a BIM project and converserly any project that is targeting futureproofing implementation may face a step change to adopt BIM processes. Due to the high interaction across all stages it may be challenging to adopt one concept at early stages and then introduce the other at a later stage.

Considering that both two concepts are relatively new concepts in healthcare, more research and industry evidence is needed to foster the adoption of those two. The interaction matrix can be used as a framework for future research which stems from the identified synergies. 
Krystallis et al. 2016. "Using BIM to integrate and achieve holistic future-proofing objectives in healthcare projects”, Construction Management and Economics

The study was only limited to interviewing healthcare construction experts and thus for linear projects the findings could be somewhat different. However, the objectives can be applied with minor modifications to sectors beyond healthcare (i.e. healthcare scenario factors may be replaced with relevant scenario factors found in the oil and gas industry etc.). Nevertheless it can be said that projects with great complexity, criticality and uncertainty can be highly benefited.

\section{References}

AIA, 2007. Integrated project delivery: a guide, s.l.: AIA California Council.

Ashworth, A., 2012. The Impact of Building Information Modelling: Transforming Construction. Construction Management and Economics, 30(2), pp. 183-185.

Bogus, S. M., Molenaar, K. R. \& Diekmann, J. E., 2006. Strategies for overlapping dependent design activities. Construction Management and Economics, 24(8), pp. 829--837.

Brand, S., 1995. How buildings learn: what happens after theyre built. s.l.:Penguin Books.

Brocki, J. \& Wearden, A., 2006. A critical evaluation of the use of interpretative phenomenological analysis (IPA) in health psychology. Psychology and Health, 21(1), pp. 87--108.

BSI, 2007. BS 1192: Collaborative production of architectural, engineering and construction information-Code of practice. London: BSI.

BSI, 2013. PAS 1192-2: Specification for information management for the capital/delivery phase of construction projects using building information modelling. In: London: BSI Standards Limited.

BSI, 2014. PAS 1192-3: Specification for information management for the operational phase of assets using building information modelling. London: BSI Standards Limited.

Bynum, P., Issa, R. R. \& Olbina, S., 2012. Building information modeling in support of sustainable design and construction. Journal of Construction Engineering and Management, 139(1), pp. 24--34.

Cabinet Office, 2011. Government Construction Strategy. London: s.n.

Capper, G., Holmes, J. \& Hudson, G., 2012. BREEAM for Healthcare-a report for NHS Estates and Facilities Policy. s.l.:s.n.

CIC, 2013. Building Information (BIM) Protocol. 1st ed. s.l.:Construction Industry Council.

Creswell, J. W. \& Clark, V. L., 2011. Designing and conducting mixed methods research. 2nd ed. Thousand Oaks: SAGE Publications Inc.

de Neufville, R., Lee, Y. S. \& Scholtes, S., 2008. Using flexibility to improve value-for-money in hospital infrastructure investments. Rotterdam, s.n., pp. 1--6.

de Neufville, R. \& Scholtes, S., 2011. Flexibility in Engineering Design. s.l.:Mit Pr.

Demian, P. \& Walters, D., 2014. The advantages of information management through building information modelling. Construction Management and Economics, 32(12), pp. 1153--1165.

DH, 2013. Health Technical Memorandum 07-07. Sustainable Health and Social Care Buildings: Planning, design, construction and refurbishment. London: Department of Health.

Dossick, C. S. \& Neff, G., 2010. Organizational divisions in BIM-enabled commercial construction. Journal of Construction Engineering and Management, 136(4), pp. 459--467. 
Krystallis et al. 2016. "Using BIM to integrate and achieve holistic future-proofing objectives in healthcare projects”, Construction Management and Economics

Eastman, C., Teicholz, P., Sacks, R. \& Liston, K., n.d. BIM handbook: A guide to building information modeling for owners, managers, architects, engineers, contractors, and fabricators. 2nd ed. Hoboken, NJ: John Wiley and Sons.

Francis, S., 2010. Plan for uncertainty: Design for change. In: M. Kagioglou \& P. Tzortzopoulos, eds. Improving Healthcare through Built Environment Infrastructure. Oxford, UK: Wiley Online Library, pp. 40--52.

Georgiadou, M. C., Hacking, T. \& Guthrie, P., 2012. A conceptual framework for future-proofing the energy performance of buildings. Energy Policy, Issue 47, pp. 145--155.

Gething, B., 2010. Design for future climate. London: Technology Strategy Board.

Giel, B. K., 2009. Return on investment analysis of building information modeling in construction. s.l.:University of Florida.

Graham, P., 2005. Design for adaptability-an introduction to the principles and basic strategies. The Australian Institute of Architects, Australia.

Grilo, A. \& Jardim-Goncalves, R., 2010. Value proposition on interoperability of BIM and collaborative working environments. Automation in Construction, 19(5), pp. 522--530.

Irizarry, J., Gheisari, M., Williams, G. \& Roper, K., 2014. Ambient Intelligence Environments for Accessing Building Information: A Healthcare Facility Management Scenario. Facilities, 32(3/4).

Javed, A., Lam, P. \& Chan, A., 2014. Change negotiation in public-private partnership projects through output specifications: an experimental approach based on game theory. Construction Management and Economics, 32(4), pp. 323--348.

Jentsch, M. F., Bahaj, A. S. \& James, P. A., 2008. Climate change future proofing of buildings-Generation and assessment of building simulation weather files. Energy and Buildings, 40(12), pp. 2148--2168.

Kendall, S., 2007. Open Building: A Systematic Approach to Designing Change-Ready Hospitals. Healthcare Design, pp. 27--33.

Korpela, J., Miettinen, R., Salmikivi, T. \& Ihalainen, J., 2015. The challenges and potentials of utilizing building information modelling in facility management: the case of the Center for Properties and Facilities of the University of Helsinki. Construction Management and Economics, 33(1), pp. 3--17.

Krygiel, E. \& Nies, B., 2008. Green BIM: successful sustainable design with building information modeling. s.l.:Sybex.

Krystallis, I., Demian, P. \& Price, A., 2012. Design of Flexible and Adaptable Healthcare facilities of the future-a BIM approach. Newcastle, s.n., pp. 222-232.

Krystallis, I., Demian, P. \& Price, A. D. F., 2013. Supporting Future-proof Healthcare Design by Narrowing the Design Space of Solutions Using Building Information Modelling. Reading, s.n., pp. 3-12.

Lahdenperä, P., 2012. Making sense of the multi-party contractual arrangements of project partnering, project alliancing and integrated project delivery. Construction Management and Economics, 30(1), pp. 57--79.

Larkin, M., Watts, S. \& Clifton, E., 2006. Giving voice and making sense in interpretative phenomenological analysis. Qualitative research in psychology, 3(2), pp. 102--120.

Larsen, G. \& Whyte, J., 2013. Safe construction through design: perspectives from the site team. Construction Management and Economics, 31(6), pp. 675--690.

Light, D., 2011. BIM Implementation - HOK buildingSMART. [Online]

Available at: http://www.thenbs.com

[Accessed 26 Augoust 2012].

Lucas, J., Bulbul, T. \& Thabet, W., 2013. An object-oriented model to support healthcare facility information management. Automation in Construction, Volume 31, pp. 281--291.

Manning, R. \& Messner, J., 2008. Case studies in BIM implementation for programming of healthcare facilities. ITcon Special Issue Case studies of BIM use, Volume 13, pp. 246--257.

Masood, T., Cuthbert, R., McFarlane, D. \& Parlikad, A. K., 2013. Information Futureproofing for Large-scale Infrastructure. s.l., IET, pp. 1-23.

NBS \& RIBA Enterprices, 2012. National BIM Report. s.l.:s.n. 
Krystallis et al. 2016. "Using BIM to integrate and achieve holistic future-proofing objectives in healthcare projects”, Construction Management and Economics

NHS Confederation, 2005. Briefing 9: Future proofing buildings for healthcare. London: NHS Confederation Distribution.

Olsson, P., Folke, C. \& Berkes, F., 2004. Adaptive comanagement for building resilience in social-ecological systems. Environmental management, 34(1), pp. 75--90.

Pati, D., Harvey, T. \& Cason, C., 2008. Inpatient Unit Flexibility: Design Characteristics of a Successful Flexible Unit. Environment and Behavior, 40(205), pp. 205--232.

Price, A. \& Lu, J., 2013. Impact of hospital space standardization on patient health and safety. Architectural Engineering and Design Management, 9(1), pp. 49-61.

Sacks, R., Koskela, L., Dave, B. A. \& Owen, R., 2010. Interaction of lean and building information modeling in construction. Journal of construction engineering and management, 136(9), pp. 968--980.

Shade, J., Olofsson, T. \& Shreyer, M., 2011. Decision-making in a model-based design process. Construction management and Economics, 29(4), pp. 371--382.

Slaughter, E. S., 2001. Design strategies to increase building flexibility. Building Research \& Information, 29(3), pp. 208--217.

Smith, J. A., 1996. Beyond the divide between cognition and discourse: Using interpretative phenomenological analysis in health psychology. Psychology and health, 11(2), pp. 261--271.

Smith, J. A., 2010. Interpretative phenomenological analysis.. Existential Analysis: Journal of the Society for Existential Analysis, 21(2).

Smith, J. A. \& Osborn, M., n.d. Interpretative Phenomenological Analysis. In: S. J. A, ed. Qualitative psychology: A practical guide to research methods. London: Sage Publications.

VHA, 2012. Future proofing our health system. Melbourne: The Victorian Healthcare Association.

Way, M. \& Bordass, B., 2007. Making feedback and post-occupancy evaluation routine 2: Soft landings involving design and building teams in improving performance. Building Research \& Information, 33(4), pp. 353-360 .

Won, J., Lee, G., Dossick, C. \& Messner, J., 2013. Where to focus for successful adoption of building information modeling within organization. Journal of Construction Engineering and Management, 139(11).

World Bank, 2010. World development report 2010: Development and climate change. Washington DC: The International Bank for Reconstruction and Development / The World Bank. 
Krystallis et al. 2016. "Using BIM to integrate and achieve holistic future-proofing objectives in healthcare projects”, Construction Management and Economics

Table 1a: Selected literature of FUTURE-PROOFING tasks aligned to project phases and emerged FUTUREPROOFING objectives

\begin{tabular}{|c|c|c|c|}
\hline Objectives & Tasks & Label & Source \\
\hline \multicolumn{4}{|l|}{ Planning } \\
\hline \multirow{5}{*}{$\begin{array}{l}\text { P-I: Future- } \\
\text { proofing brief } \\
\text { setting }\end{array}$} & $\begin{array}{l}\text { Proposals addressing future services, and planning } \\
\text { requirements }\end{array}$ & P1 & (DH, 2013) \\
\hline & $\begin{array}{l}\text { Design brief includes plans for future change. Local } \\
\text { planning objectives are taken into account }\end{array}$ & $\mathrm{P} 2$ & (DH, 2013) \\
\hline & Integration across hospital, community, primary, home & P3 & $\begin{array}{l}\text { (NHS Confederation, } \\
\text { 2005) }\end{array}$ \\
\hline & Reordering services in coherent processes & $\mathrm{P} 4$ & $\begin{array}{l}\text { (NHS Confederation, } \\
2005)\end{array}$ \\
\hline & Financial, environmental, socio-economic considerations & P5 & $\begin{array}{l}\text { (Georgiadou, et al., } \\
\text { 2012) }\end{array}$ \\
\hline \multirow{5}{*}{$\begin{array}{l}\text { P-II: } \\
\text { Investment } \\
\text { options }\end{array}$} & Redevelopment strategy to provide for future expansion & P6 & (VHA, 2012) \\
\hline & $\begin{array}{l}\text { 'No-regrets' options - investment and policy options that } \\
\text { provide benefits even when no change occurs }\end{array}$ & P7 & (World Bank, 2010) \\
\hline & $\begin{array}{l}\text { Higher 'safety margins' for change and uncertainty in } \\
\text { socioeconomic development }\end{array}$ & P8 & (World Bank, 2010) \\
\hline & $\begin{array}{l}\text { Potential developments across the area. Connections } \\
\text { with transport, commercial activities etc. }\end{array}$ & P9 & $\begin{array}{l}\text { (de Neufville \& } \\
\text { Scholtes, 2011) }\end{array}$ \\
\hline & $\begin{array}{l}\text { Consideration of future developments based on future } \\
\text { site alterations }\end{array}$ & P10 & $\begin{array}{l}\text { (de Neufville \& } \\
\text { Scholtes, 2011) }\end{array}$ \\
\hline \multirow[t]{8}{*}{$\begin{array}{l}\text { P-IV: } \\
\text { Identification } \\
\text { of flexibility }\end{array}$} & $\begin{array}{l}\text { Broad descriptions of adaptability and flexibility (future } \\
\text { end user behaviour, future changes of building layout, } \\
\text { technology lock in, upgrades etc.) }\end{array}$ & P11 & $\begin{array}{l}\text { (Pati, et al., 2008) \& } \\
\text { (Graham, 2005) }\end{array}$ \\
\hline & $\begin{array}{l}\text { Demonstration of future-proofing on parts with different } \\
\text { uses (core, movable, essential) }\end{array}$ & P12 & $\begin{array}{l}\text { (de Neufville, et al., } \\
\text { 2008) \& (Slaughter, } \\
\text { 2001) }\end{array}$ \\
\hline & Assess infrastructure regarding future developments & P13 & $\begin{array}{l}\text { (NHS Confederation, } \\
2005)\end{array}$ \\
\hline & Planning of shell space design & $\mathrm{P} 14$ & (Kendall, 2007) \\
\hline & $\begin{array}{l}\text { Flexible design to accommodate new equipment, } \\
\text { technology, changing service models }\end{array}$ & P15 & $\begin{array}{l}\text { (VHA, 2012) \& (de } \\
\text { Neufville \& Scholtes, } \\
\text { 2011) }\end{array}$ \\
\hline & $\begin{array}{l}\text { Distinction of likely expandable spaces-not expandable } \\
\text { to areas where expansion is allowed }\end{array}$ & P16 & $\begin{array}{l}\text { (VHA, 2012) \& } \\
\text { (Krystallis, et al., } \\
\text { 2012) }\end{array}$ \\
\hline & $\begin{array}{l}\text { Reversible and flexible options in case suggested } \\
\text { concerns are wrong -insurance provision }\end{array}$ & P17 & (World Bank, 2010) \\
\hline & $\begin{array}{l}\text { Weather-proofing Passive design strategies (e.g. high } \\
\text { levels internal thermal mass, inclusion of solar heat gain, } \\
\text { airtight construction, controlled ventilation, high levels } \\
\text { of insulation) }\end{array}$ & P18 & (Gething, 2010) \\
\hline \multirow{4}{*}{$\begin{array}{l}\text { P-V: } \\
\text { Responsivenes } \\
\text { s of } \\
\text { government } \\
\text { strategic goals }\end{array}$} & Awareness of government strategic framework & P19 & $(\mathrm{DH}, 2013)$ \\
\hline & $\begin{array}{l}\text { Outperforming statutory minima (go beyond } \\
\text { requirements of building regulations) }\end{array}$ & $\mathrm{P} 20$ & $\begin{array}{l}\text { (Georgiadou, et al., } \\
\text { 2012) }\end{array}$ \\
\hline & Policy making for adaptation needs to be adaptive itself & $\mathrm{P} 21$ & (World Bank, 2010) \\
\hline & $\begin{array}{l}\text { Preparedness for climate change (overheating, flood } \\
\text { issues etc.) }\end{array}$ & $\mathrm{P} 22$ & (Jentsch, et al., 2008) \\
\hline \multirow{2}{*}{$\begin{array}{l}\text { P-VI: } \\
\text { Healthcare } \\
\text { scenario } \\
\text { factors }\end{array}$} & $\begin{array}{l}\text { Best location of services based on patient pathways and } \\
\text { models of care }\end{array}$ & $\mathrm{P} 23$ & (Pati et al., 2008) \\
\hline & $\begin{array}{l}\text { Scenario analysis for long-term planning and assessment } \\
\text { of strategies under a range of possible futures }\end{array}$ & $\mathrm{P} 24$ & $\begin{array}{l}\text { (World Bank, 2010) } \\
\text { \& (Georgiadou, et al., } \\
\text { 2012) }\end{array}$ \\
\hline P-VIII: Use of & Best use of people and infrastructure & $\mathrm{P} 25$ & (NHS Confederation, \\
\hline
\end{tabular}


Krystallis et al. 2016. "Using BIM to integrate and achieve holistic future-proofing objectives in healthcare projects”, Construction Management and Economics

\begin{tabular}{|c|c|c|c|}
\hline \multirow[t]{2}{*}{ resources } & \multicolumn{3}{|r|}{$2005)$} \\
\hline & $\begin{array}{l}\text { Development control plan which tracks changes in } \\
\text { service delivery }\end{array}$ & $\mathrm{P} 26$ & $\begin{array}{l}\text { (NHS Confederation, } \\
\text { 2005) }\end{array}$ \\
\hline \multirow{2}{*}{$\begin{array}{l}\text { P-IX: Whole- } \\
\text { life } \\
\text { assessment }\end{array}$} & Preventive maintenance plans & $\mathrm{P} 27$ & $(\mathrm{DH}, 2013)$ \\
\hline & Whole-life costing & P28 & $\begin{array}{l}\text { (Graham, 2005) \& } \\
\text { (Georgiadou, et al., } \\
\text { 2012) }\end{array}$ \\
\hline $\begin{array}{l}\text { P-X: } \\
\text { Knowledge } \\
\text { systems }\end{array}$ & $\begin{array}{l}\text { Participatory design through scientific and local } \\
\text { knowledge }\end{array}$ & P29 & (World Bank, 2010) \\
\hline \multirow{6}{*}{$\begin{array}{l}\text { P-XI: Healing } \\
\text { environment }\end{array}$} & Parklands, light, art, animals, social environments & P30 & (VHA, 2012) \\
\hline & Reduced ambient noise & P31 & (VHA, 2012) \\
\hline & Evidence based principles applied for well being & P32 & $\begin{array}{l}\text { VHA, 2012) \& } \\
\text { (Price \& Lu, 2013) }\end{array}$ \\
\hline & Integrated information technology & P33 & (VHA, 2012) \\
\hline & $\begin{array}{l}\text { Healing environment alongside reduction of resource } \\
\text { consumption }\end{array}$ & P34 & (VHA, 2012) \\
\hline & Shared recreation and dining spaces & P35 & (VHA, 2012) \\
\hline
\end{tabular}

Table 1b: Selected literature of future-proofing tasks aligned to project phases and emerged future-proofing objectives (continued)

\begin{tabular}{|c|c|c|c|}
\hline $\begin{array}{l}\text { Objectives } \\
\text { (continued) }\end{array}$ & Tasks & Label & Source \\
\hline \multicolumn{4}{|l|}{ Design } \\
\hline \multirow{7}{*}{$\begin{array}{l}\text { D-I: } \\
\text { Demonstrating } \\
\text { change-readiness } \\
\text { of design }\end{array}$} & $\begin{array}{l}\text { Circulation and service infrastructure suitable to } \\
\text { accommodate change }\end{array}$ & D1 & $(\mathrm{DH}, 2013)$ \\
\hline & Buildings able to respond to climate change & D2 & $\begin{array}{l}\text { (Coley et al., } \\
\text { 2012) }\end{array}$ \\
\hline & Open-ended routes for future expansion & D3 & $\begin{array}{l}\text { NHS } \\
\text { Confederation, } \\
\text { 2005) } \\
\end{array}$ \\
\hline & $\begin{array}{l}\text { Main circulation routes to remain steadfast throughout } \\
\text { lifespan }\end{array}$ & D4 & $\begin{array}{l}\text { (NHS } \\
\text { Confederation, } \\
\text { 2005) } \\
\end{array}$ \\
\hline & Shallow plan spaces & D5 & (Kendall, 2007) \\
\hline & Building systems having the ability to expand/contract & D6 & $\begin{array}{l}\text { (VHA, 2012) \& } \\
\text { (Brand, 1995) }\end{array}$ \\
\hline & Soft spaces used as sacrificial in between hard spaces & D7 & $\begin{array}{l}\text { (NHS } \\
\text { Confederation, } \\
2005)\end{array}$ \\
\hline $\begin{array}{l}\text { D-II: } \\
\text { Demonstration of } \\
\text { maintenance } \\
\text { plans } \\
\end{array}$ & Guidance on performing maintenance tasks & D8 & $(\mathrm{DH}, 2013)$ \\
\hline \multirow{2}{*}{$\begin{array}{l}\text { D-III: } \\
\text { Demonstration of } \\
\text { flexibility plans }\end{array}$} & $\begin{array}{l}\text { Graphic demonstration of suggested flexibility and } \\
\text { preparedness }\end{array}$ & D9 & $(\mathrm{DH}, 2013)$ \\
\hline & $\begin{array}{l}\text { Demonstration of future-proofing on different parts with } \\
\text { different lifespans of the building }\end{array}$ & D10 & $\begin{array}{l}\text { (de Neufville, et } \\
\text { al., 2008) }\end{array}$ \\
\hline \multirow{5}{*}{$\begin{array}{l}\text { D-IV: Generic } \\
\text { spaces \& } \\
\text { elements }\end{array}$} & Use of generic spaces rather than bespoke & D11 & (Price \& Lu, 2013) \\
\hline & Built-in agility & D12 & $\begin{array}{l}\text { (NHS } \\
\text { Confederation, } \\
\text { 2005) } \\
\end{array}$ \\
\hline & $\begin{array}{l}\text { Provision of generic rooms for range of health } \\
\text { professionals to work }\end{array}$ & D13 & (VHA, 2012) \\
\hline & $\begin{array}{l}\text { Long-term standard based structural frames and } \\
\text { foundations }\end{array}$ & D14 & (Gething, 2010) \\
\hline & Group functions with similar requirements (multi-use) & D15 & (Krystallis, et al., \\
\hline
\end{tabular}


Krystallis et al. 2016. "Using BIM to integrate and achieve holistic future-proofing objectives in healthcare projects”, Construction Management and Economics

\begin{tabular}{llrl}
\hline & & 2013) \\
\hline \begin{tabular}{l} 
D-V: $\begin{array}{l}\text { Demonstration of } \\
\text { disruption plans }\end{array}$ \\
\cline { 2 - 3 }
\end{tabular} & $\begin{array}{l}\text { Specification requirements for different zones of the } \\
\text { building }\end{array}$ & D16 & $\begin{array}{l}\text { (Brand, 1995) \& } \\
\text { (Kendall, 2007) }\end{array}$ \\
\cline { 2 - 4 } & Ensure min. disruption of services for future upgrading & D17 & $\begin{array}{l}\text { (Georgiadou, et } \\
\text { al., 2012) }\end{array}$ \\
\cline { 2 - 4 } & Design for deconstruction & D18 & $\begin{array}{l}\text { (Brand, 1995) \& } \\
\text { (Graham, 2005) }\end{array}$ \\
\cline { 2 - 4 } & Potential change of construction and fixing detail on site & D19 & (Gething, 2010) \\
\hline
\end{tabular}

Table 1c: Selected literature of future-proofing tasks aligned to project phases and emerged future-proofing objectives (continued)

\begin{tabular}{|c|c|c|c|}
\hline $\begin{array}{l}\text { Objectives } \\
\text { (continued) }\end{array}$ & Tasks & Label & Source \\
\hline \multicolumn{4}{|l|}{ Construction } \\
\hline \multirow{2}{*}{$\begin{array}{l}\text { C-I: Publication } \\
\text { and application of } \\
\text { future-proofing } \\
\text { strategy on site }\end{array}$} & $\begin{array}{l}\text { Strategy published to contractors to avoid unprepared } \\
\text { alterations }\end{array}$ & C1 & $(\mathrm{DH}, 2013)$ \\
\hline & $\begin{array}{l}\text { Necessary changes on site do not intersect with } \\
\text { strategy }\end{array}$ & $\mathrm{C} 2$ & $(\mathrm{DH}, 2013)$ \\
\hline \multirow{2}{*}{$\begin{array}{l}\text { C-II:- Future- } \\
\text { proofing working } \\
\text { conditions }\end{array}$} & Working conditions-site accommodation & $\mathrm{C} 3$ & (Gething, 2010) \\
\hline & Temperature limitations for building processes & $\mathrm{C} 4$ & (Gething, 2010) \\
\hline \multicolumn{4}{|l|}{ Operation } \\
\hline \multirow{2}{*}{$\begin{array}{l}\text { O-I: Awareness of } \\
\text { future-proofing } \\
\text { strategy }\end{array}$} & $\begin{array}{l}\text { Provision of as-built drawings to end users by the } \\
\text { design team }\end{array}$ & $\mathrm{O} 1$ & (DH, 2013) \\
\hline & Estates managers are aware of strategy & $\mathrm{O} 2$ & $(\mathrm{DH}, 2013)$ \\
\hline \multirow[t]{2}{*}{$\begin{array}{l}\text { O-II: Feedback } \\
\text { from future-proof } \\
\text { project }\end{array}$} & $\begin{array}{l}\text { Buildings are assessed on regular basis for flexibility } \\
\text { and adaptability. Findings are used for future } \\
\text { developments }\end{array}$ & $\mathrm{O} 3$ & (DH, 2013) \\
\hline & $\begin{array}{l}\text { In case of demolition, evaluation of strategy - lessons } \\
\text { learnt }\end{array}$ & $\mathrm{O} 4$ & (World Bank, 2010) \\
\hline $\begin{array}{l}\text { O-III:- Reuse of } \\
\text { components and } \\
\text { materials }\end{array}$ & Future-proofing strategy ensures reuse of materials & $\mathrm{O} 5$ & $\begin{array}{l}\text { (DH, 2013) \& } \\
\text { (Georgiadou, et al., } \\
\text { 2012) }\end{array}$ \\
\hline
\end{tabular}

Table 2: Classification of interviewees

\begin{tabular}{cccccc}
\hline $\begin{array}{c}\text { Code } \\
\text { Name }\end{array}$ & Occupation & $\begin{array}{c}\text { Healthcare } \\
\text { Experience } \\
\text { (years) }\end{array}$ & $\begin{array}{c}\text { BIM } \\
\text { Experience } \\
\text { (years) }\end{array}$ & $\begin{array}{c}\text { Delivery } \\
\text { side }\end{array}$ & $\begin{array}{c}\text { Duration } \\
\text { (min) }\end{array}$ \\
\hline I-1 & Director of design & $11-15$ & $0-5$ & Delivery & 79 \\
\hline I-2 & Health Director & $11-15$ & $0-5$ & Procurement & 63 \\
\hline I-3 & BIM Manager & $11-15$ & over 16 & Delivery & 47 \\
\hline I-4 & Health Director & over 16 & $0-5$ & Delivery & 63 \\
\hline I-5 & BIM Manager & $11-15$ & over 16 & Delivery & 63 \\
\hline I-6 & Director of design & over 16 & $0-5$ & Delivery & 44 \\
\hline I-7 & $\begin{array}{c}\text { General Manager } \\
\text { IT }\end{array}$ & $6-10$ & $0-5$ & Procurement & 78 \\
\hline I-8 & Health Director & over 16 & $0-5$ & Delivery & 65 \\
\hline I-9 & Director of design & $6-10$ & $11-15$ & Delivery & 53 \\
\hline I-10 & $\begin{array}{c}\text { Facilities } \\
\text { Manager }\end{array}$ & $0-5$ & $6-10$ & Procurement & 43 \\
\hline I-11 & $\begin{array}{c}\text { Clinical Program } \\
\text { Manager }\end{array}$ & over 16 & none & Procurement & 61 \\
\hline I-12 & $\begin{array}{c}\text { Senior Project } \\
\text { Manager }\end{array}$ & $6-10$ & none & Procurement & 64 \\
\hline
\end{tabular}


Krystallis et al. 2016. "Using BIM to integrate and achieve holistic future-proofing objectives in healthcare projects”, Construction Management and Economics

\begin{tabular}{|c|c|c|c|c|c|}
\hline $\mathrm{I}-13$ & Director of design & over 16 & $0-5$ & Delivery & 58 \\
\hline
\end{tabular}

Table 3: Future-proofing aspirations in healthcare projects

\begin{tabular}{|c|c|c|}
\hline $\begin{array}{l}\text { future-proofing } \\
\text { Aspirations }\end{array}$ & future-proofing tasks & $\overline{\text { Label }}$ \\
\hline \multirow[t]{5}{*}{$\begin{array}{l}\text { Setting of initial future- } \\
\text { proofing targets }\end{array}$} & $\begin{array}{l}\text { Investigation of future services (home based treatment, remote care, } \\
\text { themed treatment etc.) }\end{array}$ & K1 \\
\hline & $\begin{array}{l}\text { Client awareness for future-proofing requirements, earlier in } \\
\text { discussion }\end{array}$ & K2 \\
\hline & Earlier consideration of the asset operation & K3 \\
\hline & Standardisation initiative & K4 \\
\hline & Regional requirements consideration & K5 \\
\hline \multirow[t]{4}{*}{ Investment options } & Collaborations with private healthcare and revenue for the NHS & K6 \\
\hline & Provision of commercial spaces for patient welfare & K7 \\
\hline & $\begin{array}{l}\text { Identify where investment now will save money later (whole-life } \\
\text { costing earlier in discussion) }\end{array}$ & K8 \\
\hline & Towards corporate identity & K9 \\
\hline \multirow{4}{*}{$\begin{array}{l}\text { Adaptive to future- } \\
\text { proofing needs } \\
\text { procurement method }\end{array}$} & $\begin{array}{l}\text { Fast-track mentality-build for uncertainty (i.e. big floor plates, ducts } \\
\text { on regular basis) to address uncertainty at design freeze. }\end{array}$ & K10 \\
\hline & Brief extended to project's lifespan (PFI) & K11 \\
\hline & Documented opinion of maintenance providers (IPD) & K12 \\
\hline & $\begin{array}{l}\text { Evaluation of design and construction decisions and materials } \\
\text { selection }\end{array}$ & K13 \\
\hline \multirow{11}{*}{$\begin{array}{l}\text { Necessary building } \\
\text { flexibility }\end{array}$} & Finding commonalities & K14 \\
\hline & Filtering spaces that can be changed/cannot be changed & K15 \\
\hline & Increasing clinical space/decreasing non clinical & K16 \\
\hline & Sacrificial systems & K17 \\
\hline & Finding differences among projects & K18 \\
\hline & Concrete frame more flexible than steel frame & K19 \\
\hline & Exterior prepared for expansion & K20 \\
\hline & Flexibility dependable on cost and complexity of the room & K21 \\
\hline & Long- mid- short- term elements of flexibility & K22 \\
\hline & Open spaces & K23 \\
\hline & Soft spaces & K24 \\
\hline \multirow{6}{*}{$\begin{array}{l}\text { Healthcare-specific design } \\
\text { scenario factors }\end{array}$} & Activity projections & K25 \\
\hline & Commissioning of services & K26 \\
\hline & Future services, future treatments & K27 \\
\hline & Patients flow & K28 \\
\hline & Room adjacencies & K29 \\
\hline & Room usage data & K30 \\
\hline \multirow{4}{*}{$\begin{array}{l}\text { Repeatable standardised } \\
\text { spaces }\end{array}$} & Employing limited universal repeatable spaces & K31 \\
\hline & Multi use (agile spaces) for whole life cost reduction & K32 \\
\hline & Repeatable spaces to improve service delivery & K33 \\
\hline & Standard specs for construction elements & K34 \\
\hline \multirow{5}{*}{$\begin{array}{l}\text { 'What-if' data for } \\
\text { maintenance solutions }\end{array}$} & Conditional levels of equipment linked to criticality & K35 \\
\hline & Criticality of equipment and services & K36 \\
\hline & Projections of future use for maintenance decisions & K37 \\
\hline & Maintenance equipment factors & K38 \\
\hline & $\begin{array}{l}\text { Data relevant to maintenance teams (e.g. what type of change, how to } \\
\text { deal, when to deal, how to do it etc.) }\end{array}$ & K39 \\
\hline \multirow[t]{6}{*}{ Adaptive management } & Adaptation of processes from other sectors & K40 \\
\hline & $\begin{array}{l}\text { Representations of how future-proofing is linked to clinical } \\
\text { efficiency }\end{array}$ & K41 \\
\hline & Sophisticated health trends data & K42 \\
\hline & Whole-life decisions at every stage & K43 \\
\hline & Use of evidence for estimation of changes & K44 \\
\hline & Minimum disruption of services & K45 \\
\hline
\end{tabular}


Krystallis et al. 2016. "Using BIM to integrate and achieve holistic future-proofing objectives in healthcare projects”, Construction Management and Economics

Estates managers are aware of future-proofing strategy

Table 4: BIM Capabilities related to future-proofing as discussed by the healthcare experts

\begin{tabular}{cl}
\hline Ref table & BIM Capabilities for future-proofing \\
\hline 7 & Flexible data \\
8 & Optioneering capabilities \\
9 & Project evaluation \\
10 & Standardised space catalogues \\
11 & Whole-life communication \\
12 & Whole-life costing \\
\hline
\end{tabular}

Table 5: List of Future-proofing objectives and tasks assigned to them

\begin{tabular}{|c|c|c|}
\hline \multirow{2}{*}{$\begin{array}{l}\text { Phase and future-proofing objectives } \\
\text { Planning }\end{array}$} & \multicolumn{2}{|c|}{ Labels } \\
\hline & $\begin{array}{c}\text { Literature } \\
\text { (label column of Table 1) }\end{array}$ & $\begin{array}{c}\text { Interviews } \\
\text { (label column of Table 3) }\end{array}$ \\
\hline P-I: Future-proofing brief setting & P1-P6 & K1-K3, K5 \\
\hline P-II: Investment and portfolio agenda & P7-P10 & K6-K9 \\
\hline $\begin{array}{l}\text { P-III: Adaptive-friendly procurement } \\
\text { method }\end{array}$ & - & K10-K13 \\
\hline P-IV: Identification of flexibility & P11-P18 & K14-K16, K18, K20 \\
\hline $\begin{array}{l}\mathrm{P}-\mathrm{V}: \text { Responsiveness of government } \\
\text { strategic goals }\end{array}$ & P19-P22 & - \\
\hline P-VI: Healthcare scenario factors & P23-P24 & K25-K30 \\
\hline P-VII: Standardisation agenda & - & K31, K33 \\
\hline P-VIII: Use of resources & P25-P26 & - \\
\hline P-IX: Whole-life assessment & P27-P28 & $\mathrm{K} 21, \mathrm{~K} 32, \mathrm{~K} 40, \mathrm{~K} 43$ \\
\hline P-X: Knowledge systems & P29 & $\mathrm{K} 35, \mathrm{~K} 36, \mathrm{~K} 38, \mathrm{~K} 42$ \\
\hline P-XI: Healing environment & P30-P35 & K45 \\
\hline \multicolumn{3}{|l|}{ Design } \\
\hline $\begin{array}{l}\text { D-I: Demonstrating change-readiness of } \\
\text { design }\end{array}$ & D1-D7 & K22, K23, K24 \\
\hline D-II: Demonstration of maintenance plans & D8 & K39 \\
\hline D-III: Demonstration of flexibility plans & D9-D10 & K19, K41 \\
\hline D-IV: Generic spaces \& elements & D12-D15 & K34 \\
\hline D-V: Demonstration of disruption plans & D16-D19 & K17 \\
\hline \multicolumn{3}{|l|}{ Construction } \\
\hline $\begin{array}{l}\text { C-I: Publication and application of Future- } \\
\text { proofing strategy on site }\end{array}$ & C1-C2 & - \\
\hline $\begin{array}{l}\text { C-II:- Future-proofing of working } \\
\text { conditions }\end{array}$ & C3-C4 & - \\
\hline \multicolumn{3}{|l|}{ Operation } \\
\hline O-I: Awareness of Future-proofing strategy & $\mathrm{O} 1-\mathrm{O} 2$ & K46 \\
\hline O-II: Feedback for future-proof project & O3-O4 & K37 \\
\hline O-III: Reuse of components and materials & O5 & K44 \\
\hline
\end{tabular}


Krystallis et al. 2016. "Using BIM to integrate and achieve holistic future-proofing objectives in healthcare projects”, Construction Management and Economics Table 6: Interaction table between future-proofing objectives and BIM capabilities

\begin{tabular}{|c|c|c|c|c|c|c|c|c|c|c|c|c|c|c|c|c|c|c|c|c|c|}
\hline \multicolumn{22}{|c|}{ Future-proofing objectives } \\
\hline \multirow{2}{*}{$\begin{array}{l}\text { BIM } \\
\text { capabilities }\end{array}$} & \multicolumn{11}{|c|}{ Planning } & \multicolumn{5}{|c|}{ Design } & \multicolumn{2}{|c|}{ Construction } & \multicolumn{3}{|c|}{ Operation } \\
\hline & P-I & P-II & P-IIII & P-IV & P-V & $\mathrm{P}-\mathrm{VI}$ & P-VII & P-VIII & P-IX & P-X & P-XI & D-I & D-II & D-III & D-IV & D-V & CO-I & $\begin{array}{l}\text { CO- } \\
\text { II }\end{array}$ & $0-1$ & O-II & O-III \\
\hline Flexible data & $1-4$ & 2 & & $2-4$ & 3. & $2,3,5$ & 5 & 3 & 1,4 & 2,3 & 3. & 3 & $2-4$ & 3 & 5 & 2,3 & $1-3$ & 2,3 & $1-4$ & 1,4 & 3,4 \\
\hline $\begin{array}{l}\text { Optioneering } \\
\text { capabilities }\end{array}$ & $6-9$ & 7,8 & & $6-9$ & & 6-9 & 毒 & 8. & 7,9 & 8 & 7,8 & 6-9 & & $6-9$ & 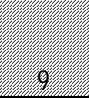 & 资 & 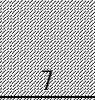 & & & 8 & 8 \\
\hline $\begin{array}{l}\text { Project } \\
\text { evaluation }\end{array}$ & $10-12$ & 11,12 & & $10-12$ & $\begin{array}{l}10, \\
11 \\
\end{array}$ & $10-12$ & 10 & 10,11 & $10-12$ & 11. & 10 & 10,12 & 10 & $10-12$ & & 11 & 10 & & 12 & $10-12$ & 10 \\
\hline $\begin{array}{l}\text { Standardised } \\
\text { space } \\
\text { catalogues }\end{array}$ & 19 & 17 & & 13 & & & $13-19$ & $14-16$ & $\begin{array}{c}15,17 \\
19 \\
\end{array}$ & 14,16 & $\begin{array}{c}14, \\
16,18\end{array}$ & & $\begin{array}{c}14-17 \\
, 19 \\
\end{array}$ & 16 & $\begin{array}{l}13,15, \\
17-19 \\
\end{array}$ & 15,15 & 17 & & $14-16$ & & 19 \\
\hline $\begin{array}{l}\text { Whole-life } \\
\text { communication }\end{array}$ & $\begin{array}{l}21,22 \\
24,26\end{array}$ & 20.26 & & $22-26$ & $20 \mathrm{e}^{2}$ & $\begin{array}{c}22 \\
24-26\end{array}$ & $\begin{array}{l}21,22, \\
24,25\end{array}$ & 20.26 & 20.22 & 21,22 & 24.26 & $22-27$ & $\begin{array}{c}21 \\
23-25\end{array}$ & $\begin{array}{c}22-25 \\
, 27 \\
\end{array}$ & $\begin{array}{l}22,23 \\
25,26 \\
\end{array}$ & $\begin{array}{c}20,21, \\
23,24 \\
27\end{array}$ & $\begin{array}{c}20,23, \\
24,26, \\
27\end{array}$ & 27 & $\begin{array}{c}20-22 \\
26\end{array}$ & 20 & 25 \\
\hline $\begin{array}{l}\text { Whole-life } \\
\text { costing }\end{array}$ & 30 & 29 & & $28-30$ & 30 & & 30 & 30 & $28-30$ & $30=$ & & 28 & 30 & $28-30$ & 28,30 & $28-30$ & 28 & & & 29,30 & 30 \\
\hline Label & no ass & ciation & & ow & & modera & & higr & & & & & & & & & & & & & \\
\hline
\end{tabular}


Krystallis et al. 2016. "Using BIM to integrate and achieve holistic future-proofing objectives in healthcare projects”, Construction Management and Economics

Table 7: Flexible data - Index, Interactions and Evidence from practice

\begin{tabular}{cll}
\hline Index & Interactions & \multicolumn{1}{c}{ Evidence from practice } \\
\hline 1 & $\begin{array}{l}\text { Gradual data - } \\
\text { Data } \\
\text { production } \\
\text { aligned to } \\
\text { each phase }\end{array}$ & $\begin{array}{l}\text { "At the end of Stage } 5 \text { in construction you want the COBie data to include ... a serial } \\
\text { number of every single light in that four bed bay. You do not need that at Stage } 2 \\
\text { though. At Stage 2, COBie is there to tell you that there will be a light which gives } \\
\text { around } 1000 \text { lumens." }\end{array}$ \\
\hline 2 & $\begin{array}{l}\text { Expanded use } \\
\text { of BIM to } \\
\text { non-design } \\
\text { tasks }\end{array}$ & $\begin{array}{l}\text { "The ability to give the data of what real life is. E.g. a light bulb with all the real } \\
\text { specifications; if I need to get a replacement I want to be able to print a shopping list and } \\
\text { just go a get a buy it." }\end{array}$ \\
\hline $\begin{array}{l}\text { Adaptable } \\
\text { data for } \\
\text { various actors }\end{array}$ & $\begin{array}{l}\text { "The data that a model carries can be used for a whole range of different subjects. From } \\
\text { logistics, safety walkthroughs, visualizations, material take off etc. but it is not a }\end{array}$ \\
\hline 4 & $\begin{array}{l}\text { Maintained } \\
\text { data } \\
\text { availability }\end{array}$ & $\begin{array}{l}\text { "The key from my point of view is ensuring the information will exist in an existing } \\
\text { facility in a form that can be reused 3, 5, 10 years down the track." }\end{array}$ \\
\hline 5 & $\begin{array}{l}\text { Online live } \\
\text { databases } \\
\text { linked to the } \\
\text { model }\end{array}$ & $\begin{array}{l}\text { "The idea is to build a BIM library of standard components and therefore you do not } \\
\text { need to design the bedroom. What we actually did is having three standard bedrooms. } \\
\text { All P21+ are going to be using just three models." }\end{array}$ \\
\hline
\end{tabular}

Table 8: Optioneering capabilities - Index, Interactions and Evidence from practice

\begin{tabular}{cll}
\hline Index & Interactions & \multicolumn{1}{c}{ Evidence from practice } \\
\hline 6 & $\begin{array}{l}\text { Collaborativ } \\
\text { e 'what if' } \\
\text { scenarios }\end{array}$ & $\begin{array}{l}\text { "BIM is a process which allows all actors to work on various scenarios on the same } \\
\text { model. All the components put in by the different disciplines can be seen and tested } \\
\text { within the virtual model." }\end{array}$ \\
\hline 7 & $\begin{array}{l}\text { Design } \\
\text { integrity }\end{array}$ & $\begin{array}{l}\text { "Inevitably it does not matter how much you do in 2D if somebody will forget that that } \\
\text { column is actually there, whereas in BIM you cannot simply forget that." }\end{array}$ \\
\hline 8 & $\begin{array}{l}\text { Multi- } \\
\text { purpose } \\
\text { scenarios }\end{array}$ & $\begin{array}{l}\text { "I think there is the case of having the design package on one end, and the software } \\
\text { packages that look at flows and occupancy levels on the other end and then joining } \\
\text { them together." }\end{array}$ \\
\hline $\begin{array}{l}\text { Quicker } \\
\text { check of } \\
\text { design } \\
\text { alternatives }\end{array}$ & $\begin{array}{l}\text { "Now it is much quicker [the design process] and because it is quicker we can manage } \\
\text { our risk better because ... we are looking at those optioneering possibilities and } \\
\text { because we are able to put all those influences and drivers into the equation." }\end{array}$ \\
\hline
\end{tabular}

Table 9: Project evaluation - Index, Interactions and Evidence from practice

\begin{tabular}{cll}
\hline Index & Interactions & \multicolumn{1}{c}{ Evidence from practice } \\
\hline 10 & $\begin{array}{l}\text { Benchmarks } \\
\text { and } \\
\text { recommendati } \\
\text { ons }\end{array}$ & $\begin{array}{l}\text { "You can’t do any other way that it is quicker than the confidence of using BIM and } \\
\text { you can find where the sensitivities are in the design." }\end{array}$ \\
\hline 11 & $\begin{array}{l}\text { Comparison of } \\
\text { existing } \\
\text { condition } \\
\text { against future } \\
\text { requirements }\end{array}$ & $\begin{array}{l}\text { "I would want to know the 3D size of the space, what is in the space and how it } \\
\text { worked. Patient flows that have been assumed. If I've got that information in place, } \\
\text { remodel what I currently have against my new requirements." }\end{array}$ \\
\hline 12 & $\begin{array}{l}\text { Quantification } \\
\text { of future- } \\
\text { proofing }\end{array}$ & $\begin{array}{l}\text { "But because you could develop a BIM model and then use it to demonstrate at the } \\
\text { early stage of the design process the end use of the facility and be able to say that not } \\
\text { only have we thought about future-proofing, we can actually quantify future- } \\
\text { proofing." }\end{array}$ \\
\hline
\end{tabular}


Krystallis et al. 2016. "Using BIM to integrate and achieve holistic future-proofing objectives in healthcare projects”, Construction Management and Economics

Table 10: Standardised space catalogues- Index, Interactions and Evidence from practice

\begin{tabular}{|c|c|c|}
\hline Index & Interactions & Evidence from practice \\
\hline 13 & $\begin{array}{l}\text { Have something } \\
\text { to work with - } \\
\text { not starting } \\
\text { from scratch }\end{array}$ & $\begin{array}{l}\text { "When you create a BIM model you are constructing it in a sense you can do it more } \\
\text { quickly and more efficiently if you are dragging big component parts out of a } \\
\text { catalogue rather than starting from scratch." }\end{array}$ \\
\hline 14 & $\begin{array}{l}\text { Increases } \\
\text { familiarity of } \\
\text { staff with } \\
\text { workspace }\end{array}$ & $\begin{array}{l}\text { "When staff is moving from one hospital to another there are actually no unfamiliar } \\
\text { spaces so they can do their work more efficiently. So we are able to say how design } \\
\text { is not mirrored it is repeated, i.e. the bed is always on the left for example and the } \\
\text { clinical zone is always on the patients right hand side." }\end{array}$ \\
\hline 15 & $\begin{array}{l}\text { Minimises the } \\
\text { need for } \\
\text { disruptive } \\
\text { stakeholder } \\
\text { engagement } \\
\end{array}$ & $\begin{array}{l}\text { "It will reduce the amount of stakeholder engagement that is required therefore you } \\
\text { do not have to take the clinicians away from their day jobs to be designing bedrooms } \\
\text { again. These will be available as BIM data drops to be used." }\end{array}$ \\
\hline 16 & $\begin{array}{l}\text { Reduction of } \\
\text { clinical errors }\end{array}$ & $\begin{array}{l}\text { "There are also benefits to staff because those that have familiarity of the room and } \\
\text { know where equipment is placed... so you have links to reduce clinical errors, when } \\
\text { you have all these sort of design features being repeated." }\end{array}$ \\
\hline 17 & $\begin{array}{l}\text { Supply chain } \\
\text { cost reduction }\end{array}$ & $\begin{array}{l}\text { "And when use those [same] spaces in BIM you could then share that BIM } \\
\text { information with the suppliers and the suppliers would hold that information which } \\
\text { would cut their cost as well." }\end{array}$ \\
\hline 18 & $\begin{array}{l}\text { Repeatable } \\
\text { design is linked } \\
\text { to evidence and } \\
\text { experience }\end{array}$ & $\begin{array}{l}\text { "An anecdote were consultant X always knows what he wants e.g. six single beds } \\
\text { etc. because that is how he has done for the past } 20 \text { years ...but there are no actual } \\
\text { evidence what he wants is going to help the patient so what we have done is to try } \\
\text { and take the subjectivity away." }\end{array}$ \\
\hline 19 & $\begin{array}{l}\text { Specifications } \\
\text { become default } \\
\text { and automated } \\
\text { input }\end{array}$ & $\begin{array}{l}\text { "Regarding future-proofing at least if we get our components right we can clarify } \\
\text { our standard specifications, we can cut a list of element together ... into the BIM } \\
\text { model almost automatically, on the drawings, it will be on the business spec etc." }\end{array}$ \\
\hline
\end{tabular}


Krystallis et al. 2016. "Using BIM to integrate and achieve holistic future-proofing objectives in healthcare projects”, Construction Management and Economics

Table 11: Whole-life communication - Index, Interactions and Evidence from practice

\begin{tabular}{|c|c|c|}
\hline Index & Interactions & Evidence from practice \\
\hline 20 & $\begin{array}{l}\text { Virtual } \\
\text { representation } \\
\text { and roadmap of } \\
\text { future-proofing }\end{array}$ & $\begin{array}{l}\text { "[BIM] is the most efficient way of achieving FUTURE-PROOFING and also the } \\
\text { most efficient way of communicating that to the stakeholders because you can } \\
\text { actually show them the 3D spaces and you can actually have a road map for what you } \\
\text { got there. And it can all be edited in space." }\end{array}$ \\
\hline 21 & $\begin{array}{l}\text { Operational } \\
\text { knowledge }\end{array}$ & $\begin{array}{l}\text { "I am immediately thinking of operational knowledge because e.g. we operate a } \\
\text { hospital as of today and there will be } 40 \text { people running that project, they will all have } \\
\text { a massive amount of knowledge about what works well in that hospital... if we could } \\
\text { link that feedback from people actually using the hospital back to BIM databases." }\end{array}$ \\
\hline 22 & $\begin{array}{l}\text { Communicatio } \\
\text { n of working } \\
\text { specifications }\end{array}$ & $\begin{array}{l}\text { "I would like to know about adjacencies. In a healthcare environment I think it would } \\
\text { be information from the healthcare professional and where they think and how a } \\
\text { hospital is going to work in the future." }\end{array}$ \\
\hline 23 & $\begin{array}{l}\text { Fully } \\
\text { multidisciplina } \\
\text { ry integrated } \\
\text { model }\end{array}$ & $\begin{array}{l}\text { "This is all about looking at a full integrated model, bringing the right aspects e.g. fire } \\
\text { engineering, so that you have got a model that reflects good fire engineering practice; } \\
\text { that shows how the services function, it shows you patient flows, visitor flows etc." }\end{array}$ \\
\hline 24 & $\begin{array}{l}\text { Non-physical } \\
\text { presence for } \\
\text { design reviews } \\
\text { and workshops }\end{array}$ & $\begin{array}{l}\text { "The days of actually having a great big workshop in a great big room and inviting } \\
\text { lots of people that is probably going to be unnecessary and things are going to be } \\
\text { more virtually between teams." }\end{array}$ \\
\hline 25 & $\begin{array}{l}\text { Standardised } \\
\text { information } \\
\text { process flows }\end{array}$ & $\begin{array}{l}\text { "With BIM you can build an international team, e.g. with the airbus various } \\
\text { components are built by various teams in various countries and it is all transported to } \\
\text { France where it is being assembled. The process is accomplished by a multinational } \\
\text { team." }\end{array}$ \\
\hline 26 & $\begin{array}{l}\text { Volumetric } \\
\text { process- } \\
\text { understandable } \\
\text { by non-experts }\end{array}$ & $\begin{array}{l}\text { "The process becomes volumetric. We can model a room and present it to the client. } \\
\text { That gives them confidence of how something can work on a particular way." }\end{array}$ \\
\hline 27 & $\begin{array}{l}\text { Visual } \\
\text { precaution tool }\end{array}$ & $\begin{array}{l}\text { “...a lot of those problems have to be solved with an expense on site and BIM is } \\
\text { trying to reduce that cost." }\end{array}$ \\
\hline
\end{tabular}

Table 12: Whole-life costing - Index, Interactions and Evidence from practice

\begin{tabular}{cll}
\hline Index & Interactions & \multicolumn{1}{c}{ Evidence from practice } \\
\hline 28 & $\begin{array}{l}\text { Classes } \\
\text { minimisation- } \\
\text { cost savings }\end{array}$ & $\begin{array}{l}\text { "BIM can improve the clashes within the construction because the Mechanical } \\
\text { engineer will be more aware of what the architectural drawing will look like. If they } \\
\text { sort it out in the BIM model in the first place, then when then they actually build it } \\
\text { they will get the services around the installed components because they will know } \\
\text { about it." }\end{array}$ \\
\hline 29 & $\begin{array}{l}\text { Cheaper check } \\
\text { of alternative } \\
\text { solutions }\end{array}$ & $\begin{array}{l}\text { "Future-proofing is possible with BIM and it will enable us to model a building with } \\
\text { different given parameters more quickly and cheaply than otherwise." }\end{array}$ \\
\hline 30 & $\begin{array}{l}\text { Reducing the } \\
\text { cost of } \\
\text { resources }\end{array}$ & $\begin{array}{l}\text { "In your BIM model you could have those scenarios and you could then optioneer } \\
\text { those and check what is the most efficient way to provide a space now which meets } \\
\text { most of those scenarios with the least additional cost [of resources]." }\end{array}$ \\
\hline
\end{tabular}




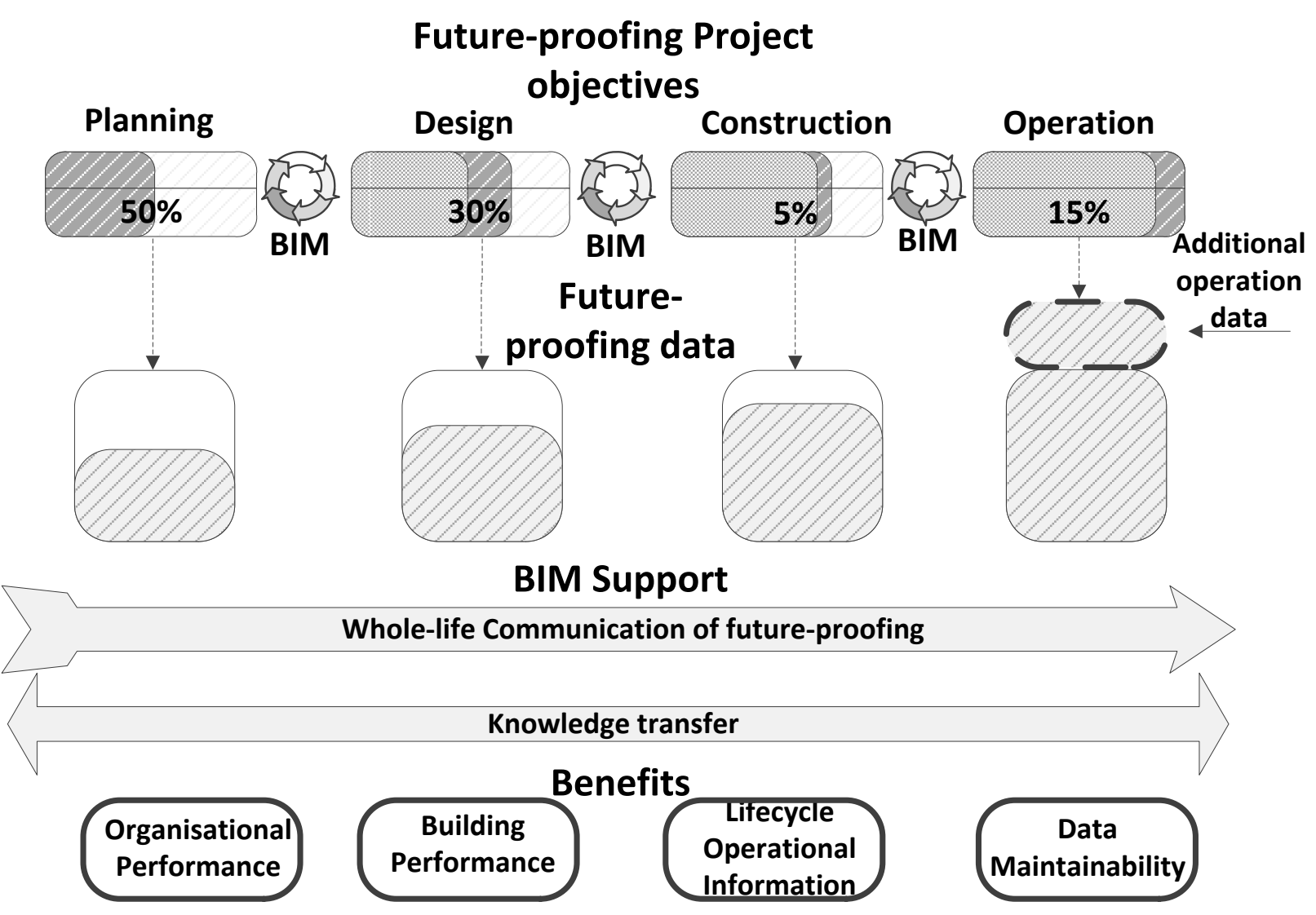

Figure 1: Benefits realisation for implementation of future-proofing using BIM 